\title{
Antiproliferative and cell apoptosis-inducing activities of compounds from Buddleja davidii in Mgc-803 cells
}

\author{
Jian $\mathrm{Wu}^{\dagger}$, Wenshi $\mathrm{Yi}^{\dagger}$, Linhong Jin, Deyu Hu and Baoan Song ${ }^{*}$
}

\begin{abstract}
Background: Buddleja davidii is widely distributed in the southwestern region of China. We have undertaken a systematic analysis of $B$. davidii as a Chinese traditional medicine with anticancer activity by isolating natural products for their activity against the human gastric cancer cell line Mgc-803 and the human breast cancer cell line Bcap-37.

Results: Ten compounds were extracted and isolated from B. davidii, among which colchicine was identified in B. davidii for the first time. The inhibitory activities of these compounds were investigated in Mgc-803, Bcap-37 cells in vitro by MTT [3-(4,5-dimethylthiazol-2-yl)-2,5-diphenyltetrazolium bromide] assay, and the results showed that luteolin and colchicine had potent inhibitory activities against the growth of Mgc-803 cells. Subsequent fluorescence staining and flow cytometry analysis indicated that these two compounds could induce apoptosis in Mgc-803 cells. The results also showed that the percentages of early apoptotic cells (Annexin $\mathrm{V}^{+} / \mathrm{PI}^{-}$, where $\mathrm{Pl}$ is propidium iodide) and late apoptotic cells (Annexin $\mathrm{V}+/ \mathrm{PI}+$ ) increased in a dose- and time-dependent manner. After $36 \mathrm{~h}$ of incubation with luteolin at $20 \mu \mathrm{M}$, the percentages of cells were approximately $15.4 \%$ in early apoptosis and $43.7 \%$ in late apoptosis; after $36 \mathrm{~h}$ of incubation with colchicine at $20 \mu \mathrm{M}$, the corresponding values were $7.7 \%$ and $35.2 \%$, respectively.
\end{abstract}

Conclusions: Colchicine and luteolin from B. davidii have potential applications as adjuvant therapies for treating human carcinoma cells. These compounds could also induce apoptosis in tumor cells.

Keywords: Buddleja davidii, Anticancer activity, Colchicine, Luteolin

\section{Background}

Buddleja belongs to the Loganiaceae family and has a pantropical distribution across South Asia, Africa, and America [1]. This genus comprises approximately 100 species of wood perennials and shrubs. The roots, leaves, and flowers of various species of Buddleja are used in folk medicine in several parts of the world [2]. Various bioactivities, including antimicrobial activity against Staphylococcus aureus, as well as antihepatotoxic, antirheumatic, antiprotozoal, and antifungal properties of isolated compounds from Buddleja have been reported [3-10]. The application of the

\footnotetext{
* Correspondence: songbaoan22@yahoo.com

${ }^{\dagger}$ Equal contributors

State Key Laboratory Breeding Base of Green Pesticide and Agricultural Bioengineering, Key Laboratory of Green Pesticide and Agricultural
Bioengineering, Ministry of Education, Guizhou University, Huaxi District Bioengineering, Key Laboratory of Green Pesticide and Agricultural
Bioengineering, Ministry of Education, Guizhou University, Huaxi District, Guiyang 550025, China
}

(c) 2012 Wu et al.; licensee BioMed Central Ltd. This is an Open Access article distributed under the terms of the Creative Commons Attribution License (http://creativecommons.org/licenses/by/2.0), which permits unrestricted use, distribution, and reproduction in any medium, provided the original work is properly cited.

poultice or lotion of a number of species of Buddleja to treat wounds has also been documented [11,12].

Buddleja davidii is a perennial herbaceous plant widely distributed in the Chinese provinces of Yunnan, Guizhou, Sichuan, and Xizang. In Chinese folk medicine, the roots, leaves, and stems of this plant are consumed by drinking an infusion with alcoholic content for the treatment of rheumatism, cough, and fractures.

Studies have evaluated crude extract and different extract partitions from Buddleja for their free radical scavenger capacity; neural tissue protection [13]; as well as anticonvulsant [14], antioxidant [15], anti-plasmodium [16], antiviral [17], anti-inflammatory [18,19], and antifungal [9] activities. To the best of our knowledge, the anticancer activity of $B$. davidii has not been studied yet. The aim of this study was to investigate the anticancer property of isolated compounds of $B$. davidii. 
The following 10 compounds were isolated from $B$. davidii grown in Guizhou and identified by spectroscopic and physicochemical analysis: luteolin 1, naringenin 2 , puerarin 3 , rutin 4 , quercetin 5 , hesperetin $\mathbf{6}$, and acacetin-7-O- $\alpha$-L-rhamno- pyranosyl(1-6)- $\beta$-D-glucopyranoside 7 (flavonoids); stigmasterol 8 (steroid); ferulic acid 9 (phenylpropanoid); and colchicine 10 ( alkaloid ). Colchicine $\mathbf{1 0}$ was extracted from B. davidii for the first time. All compounds were subjected to bioassay against the human gastric cancer cell line Mgc-803 and the human breast cancer cell line Bcap-37 in vitro using the MTT [3-(4,5-dimethylthiazol-2-yl)-2,5-diphenyltetrazolium bromide] method. Luteolin had more potent inhibitory activities against the growth of Mgc-803 cells than the other compounds, and colchicine exhibited high activities against the growth of these cells as well. Further investigations of luteolin and colchicine were thus carried out in Mgc-803 and Bcap-37 cells. Their IC50 values were determined. Fluorescent staining and flow cytometry analysis indicated that both compounds could induce apoptosis in Mgc-803 cells. To the best of our knowledge, this is the first study to report on the apoptosis-inducing and antitumor activities of luteolin and colchicine in Mgc-803 and Bcap-37 cells.

\section{Results and discussion \\ Chemistry}

Dried B. davidii samples collected from Guizhou were studied, and the following compounds were isolated from $n$-butanol extracts, which were identified based on their physicochemical as well as spectroscopic data as luteolin (1), naringenin (2), puerarin (3), rutin (4), quercetin (5), hesperetin (6), acacetin-7-O- $\alpha$-L-rhamnopyranosyl (1-6)- $\beta$-D-glucopyranoside (7, flavonoids), stigmasterol (8, steroid), ferulic acid (9, phenylpropanoid); , and colchicine (10, alkaloid). Among them, colchicine (10) was obtained from the plants for the first time. All the isolated compounds were shown in Figure 1.

Compound 1 (luteolin [20]), yellow crystal; m.p. 328$330^{\circ} \mathrm{C}$; molecular formula: $\mathrm{C}_{15} \mathrm{H}_{10} \mathrm{O}_{6}$; ESI-MS: $m / z 287$ $[\mathrm{M}+\mathrm{H}]+, \quad 309 \quad[\mathrm{M}+\mathrm{Na}]+;{ }^{1} \mathrm{H} \quad \mathrm{NMR} \quad$ (DMSO-d6, $500 \mathrm{MHz}) \delta: 7.43\left(1 \mathrm{H}, \mathrm{s}, \mathrm{H}-2^{\prime}\right), 7.40(1 \mathrm{H}, \mathrm{d}, J=8.4 \mathrm{~Hz}$, H-6'), 6.89 (1 H, d, J=8.4 Hz, H-5'), 6.68 (1 H, br, s, H8), 6.45 (1 H, s, H-3), 6.19 (1 H, br, s, H-6); ${ }^{13} \mathrm{C}$ NMR (DMSO-d6, $125 \mathrm{MHz}$ ) 8: 182.2 (C-4), 164.6 (C-7), 164.4 (C-3), 161.9 (C-9), 157.8 (C-5), 150.2 (C-4'), 146.2 (C-3'), 122.0 (C-1'), 119.5 (C-6'), 116.5 (C-5'), 113.8 (C-2'), 104.2 (C-2), 103.4 (C-10), 98.3 (C-8), 94.3 (C-6).

Compound 2 (naringenin [21]), yellow amorphous crystal; m.p. $253-255^{\circ} \mathrm{C}$; molecular formula: $\mathrm{C}_{15} \mathrm{H}_{12} \mathrm{O}_{5}$; ESI-MS: $m / z 271$ [M-H] ${ }^{-} ;{ }^{1} \mathrm{H}$ NMR $\left(\mathrm{CD}_{3} \mathrm{OD}, 500 \mathrm{MHz}\right.$ ) $\delta$ : $7.28\left(2 \mathrm{H}, \mathrm{d}, J=8.4 \mathrm{~Hz}, \mathrm{H}-2^{\prime}, 6^{\prime}\right), 6.79(2 \mathrm{H}, \mathrm{d}$, $\left.J=8.2 \mathrm{~Hz}, \mathrm{H}-3^{\prime}, 5^{\prime}\right), 5.86(1 \mathrm{H}, \mathrm{d}, J=1.5 \mathrm{~Hz}, \mathrm{H}-8), 5.31$
(1 H, d, J=1.4 Hz, H-6), $3.12(1 \mathrm{H}, \mathrm{d}, J=0.9 \mathrm{~Hz}, \mathrm{H}-2)$, 3.06 (1 H, brs, H-3a), 2.65 (1 H, brs, H-3b); ${ }^{13} \mathrm{C}$ NMR (CD3OD, $125 \mathrm{MHz}$ ) 8: 196.5 (C-4), 167.0 (C-7), 164.1 (C-5), 163.6 (C-9), 157.7 (C-4'), 129.7 (C-1'), 127.7 (C-2', C-6'), 114.9 (C-3/), 1 (C-5'), 102.0 (C-10), 95.7 (C-6), 94.8 (C-8), 79.1 (C-2), 42.7 (C-3).

Compound 3 (puerarin [22,23]), white crystal; m.p. 189- $191^{\circ} \mathrm{C}$; molecular formula: $\mathrm{C}_{21} \mathrm{H}_{20} \mathrm{O}_{9}$; ESI-MS: $\mathrm{m} / z$ $415[\mathrm{M}-\mathrm{H}]^{-}, 417[\mathrm{M}+\mathrm{H}]^{+}, 439[\mathrm{M}+\mathrm{Na}]^{+}, 455[\mathrm{M}+\mathrm{K}]^{+}$; ${ }^{1} \mathrm{H}$ NMR (CD3OD, $\left.500 \mathrm{MHz}\right) \delta: 8.03\left({ }^{1} \mathrm{H}, \mathrm{d}, J=9 \mathrm{~Hz}\right.$, $\mathrm{H}-5), 6.98(1 \mathrm{H}, \mathrm{d}, J=9 \mathrm{~Hz}, \mathrm{H}-6), 7.35(2 \mathrm{H}, \mathrm{d}, J=9 \mathrm{~Hz}$, $\mathrm{H}-2,6), 6.83(2 \mathrm{H}, \mathrm{d}, J=9 \mathrm{~Hz}, \mathrm{H}-3,5), 8.16$ (1 H, s, H-2), $5.09(1 \mathrm{H}, \mathrm{d}, J=10 \mathrm{~Hz}, \mathrm{H}-1) ;{ }^{13} \mathrm{C} \mathrm{NMR}\left(\mathrm{CD}_{3} \mathrm{OD}\right.$, $125 \mathrm{MHz})$ \&: 176.9 (C-4), 161.7 (C-7, 9), $157.4\left(\mathrm{C}-4^{\prime}\right)$, 153.2 (C-2), 130.1 (C-2', 6'), $126.8\left(\mathrm{C}-1^{\prime}, 5\right), 124.2$ (C-3), 122.9 (C-10), 117.1 (C-3', C-5'), 114.9 (C-6), 111.8 (C-8), $81.4\left(\mathrm{C}-5^{\prime \prime}\right), 78.7\left(\mathrm{C}-3^{\prime \prime}\right), 74.3\left(\mathrm{C}-1^{\prime \prime}\right), 71.6\left(\mathrm{C}-4^{\prime \prime}\right), 70.4$ $\left(\mathrm{C}-2^{\prime \prime}\right), 61.4\left(\mathrm{C}-6^{\prime \prime}\right)$.

Compound 4 (rutin [24,25]), yellow crystal; m.p. 188$190^{\circ} \mathrm{C}$; molecular formula: $\mathrm{C}_{27} \mathrm{H}_{30} \mathrm{O}_{16}$; ESI-MS: $m / z 609$ $[\mathrm{M}-\mathrm{H}]^{-}, \quad 633 \quad[\mathrm{M}+\mathrm{Na}]^{+} ;{ }^{1} \mathrm{H} \quad \mathrm{NMR} \quad$ (DMSO-d6, $500 \mathrm{MHz}) \delta: 7.56\left(1 \mathrm{H}, \mathrm{d}, J=2.0 \mathrm{~Hz}, \mathrm{H}-2^{\prime}\right), 7.54(1 \mathrm{H}, \mathrm{d}$, $\left.J=2.0 \mathrm{~Hz}, \mathrm{H}-6^{\prime}\right), 6.86\left(1 \mathrm{H}, \mathrm{d}, J=9.0 \mathrm{~Hz}, \mathrm{H}-5^{\prime}\right), 6.39$ $\left(1 \mathrm{H}, \mathrm{d}, J=1.9 \mathrm{~Hz}, \mathrm{H}-3^{\prime}\right), 6.20\left(1 \mathrm{H}, \mathrm{d}, J=1.9 \mathrm{~Hz}, \mathrm{H}-4^{\prime}\right)$, $5.36\left(1 \mathrm{H}, \mathrm{d}, J=7.3 \mathrm{~Hz}, \mathrm{H}-1^{\prime \prime}\right), 4.54(1 \mathrm{H}, \mathrm{d}, J=1.3 \mathrm{~Hz}$, $\left.1^{\prime \prime \prime}-\mathrm{H}\right) ;{ }^{13} \mathrm{C}$ NMR (DMSO-d6, $\left.125 \mathrm{MHz}\right) \delta: 177.8$ (C-4), 164.615 (C-7), 161.7 (C-5), 157.1 (C-9), 156.9 (C-2), $148.9\left(\mathrm{C}-4^{\prime}\right), 145.3\left(\mathrm{C}-3^{\prime}\right), 133.8(\mathrm{C}-3), 122.1\left(\mathrm{C}-1^{\prime}\right), 121.7$ $\left(\mathrm{C}-6^{\prime}\right), 116.8\left(\mathrm{C}-5^{\prime}\right), 115.8\left(\mathrm{C}-2^{\prime}\right), 104.5(\mathrm{C}-10), 101.7(\mathrm{C}-$ $\left.1^{\prime \prime}\right), 101.3\left(\mathrm{C}-1^{\prime \prime \prime}\right), 99.2$ (C-6), $94.1(\mathrm{C}-8), 76.3\left(\mathrm{C}-3^{\prime \prime}\right)$, $76.1\left(\mathrm{C}-5^{\prime \prime}\right), 74.5\left(\mathrm{C}-2^{\prime \prime}\right), 72.3\left(\mathrm{C}-4^{\prime \prime \prime}\right), 71.0\left(\mathrm{C}-3^{\prime \prime \prime}\right), 70.9$ $\left(\mathrm{C}-2^{\prime \prime \prime}\right), 70.5\left(\mathrm{C}-4^{\prime \prime}\right), 68.8\left(\mathrm{C}-5^{\prime \prime \prime}\right), 67.4\left(\mathrm{C}-6^{\prime \prime}\right), 18.3(\mathrm{C}-$ $\left.6^{\prime \prime \prime}\right)$.

Compound 5 (quercetin [26]), yellow powder; m.p. 306-308 ${ }^{\circ} \mathrm{C}$; molecular formula: $\mathrm{C}_{15} \mathrm{H}_{10} \mathrm{O}_{7}$; ESI-MS: $\mathrm{m} / z$ $301[\mathrm{M}-\mathrm{H}]^{-}, 325[\mathrm{M}+\mathrm{Na}]^{+}, 341[\mathrm{M}+\mathrm{K}]^{+} ;{ }^{1} \mathrm{H} \quad \mathrm{NMR}$ $\left(\right.$ DMSO $\left.\mathrm{d}_{6}, 500 \mathrm{MHz}\right) \delta: 7.64\left(1 \mathrm{H}, \mathrm{d}, J=2.3 \mathrm{~Hz}, \mathrm{H}-2^{\prime}\right)$, $7.53\left(1 \mathrm{H}, \mathrm{dd}, J=8.6 \mathrm{~Hz}, J=2.3 \mathrm{~Hz}, \mathrm{H}-6^{\prime}\right), 6.78(1 \mathrm{H}, \mathrm{d}$, $\left.J=8.6 \mathrm{~Hz}, \mathrm{H}-5^{\prime}\right), 6.28(1 \mathrm{H}, \mathrm{d}, J=2.3 \mathrm{~Hz}, \mathrm{H}-8), 6.20(1 \mathrm{H}$, $\mathrm{d}, J=1.8 \mathrm{~Hz}, \mathrm{H}-6) ;{ }^{13} \mathrm{C}$ NMR (DMSO-d $\left.6,125 \mathrm{MHz}\right) \delta$ : 176.4 (C-4), 164.4 (C-7), 161.2 (C-5), 156.7 (C-9), 148.2 (C-2), $147.3\left(\mathrm{C}-3^{\prime}\right), 145.6\left(\mathrm{C}-4^{\prime}\right), 136.3(\mathrm{C}-3), 122.5(\mathrm{C}-$ $\left.1^{\prime}\right), 120.5\left(\mathrm{C}-6^{\prime}\right), 116.1\left(\mathrm{C}-5^{\prime}\right), 115.6\left(\mathrm{C}-2^{\prime}\right), 103.5$ (C-10), 98.7 (C-6), 93.9 (C-8).

Compound 6 (hesperetin [27]), white powder; m.p. 216-218 ${ }^{\circ} \mathrm{C}$; molecular formula: $\mathrm{C}_{16} \mathrm{H}_{14} \mathrm{O}_{6}$; ESI-MS: $\mathrm{m} / z$ $301[\mathrm{M}-\mathrm{H}]^{-}, 303[\mathrm{M}+\mathrm{H}]^{+}, 325[\mathrm{M}+\mathrm{Na}]^{+} ;{ }^{1} \mathrm{H} \quad \mathrm{NMR}$ $\left(\right.$ DMSO $\left.\mathrm{d}_{6}, 6500 \mathrm{MHz}\right) \delta: 6.91(1 \mathrm{H}, \mathrm{dd}, J=8.4,2.4 \mathrm{~Hz}$, $\mathrm{H}-6 /), 6.90(1 \mathrm{H}, \mathrm{d}, J=2.4 \mathrm{~Hz}, \mathrm{H}-2 \prime), 6.88(1 \mathrm{H}, \mathrm{d}$, $J=8.4 \mathrm{~Hz}, \mathrm{H}-5 /), 5.87(1 \mathrm{H}, \mathrm{d}, J=2.4 \mathrm{~Hz}, \mathrm{H}-8), 5.86(1 \mathrm{H}$, d, $J=2.4 \mathrm{~Hz}, \mathrm{H}-6), 5.38$ (1 H, dd, $J=12.1,2.8 \mathrm{~Hz}, \mathrm{H}-2)$, 3.73 (s), 3.16 (1 H, dd, J=17.2, $12.1 \mathrm{~Hz}, \mathrm{H}-3 \mathrm{~b}), 2.68$ (1 H, dd, $J=17.2,2.8 \mathrm{~Hz}, \mathrm{H}-3 \mathrm{a}) ;{ }^{13} \mathrm{C}$ NMR (DMSO-d ${ }_{6}$, 125 MHz) \&: 196.7 (C-4), 167.2 (C-7), 164.0 (C-5), 163.3 
<smiles>O=c1cc(-c2ccc(O)c(O)c2)oc2cc(O)cc(O)c12</smiles><smiles>O=c1c(-c2ccc(O)cc2)coc2c(C3OC(CO)[C@@H](O)[C@H](O)[C@H]3O)c(O)ccc12</smiles><smiles>O=c1c(O)c(-c2ccc(O)c(O)c2)oc2cc(O)cc(O)c12</smiles>

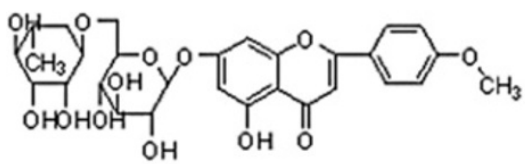

7

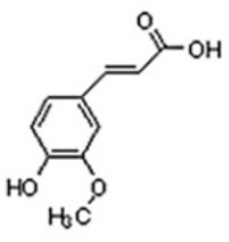

9<smiles>O=C1CC(c2ccc(O)cc2)Oc2cc(O)cc(O)c21</smiles><smiles>O=c1c(OC(O)C(O)C(O)C(O)C(O)O)c(-c2ccc(O)c(O)c2)oc2cc(O)cc(O)c12</smiles><smiles>COc1ccc(C2CC(=O)c3c(O)cc(O)cc3O2)cc1O</smiles><smiles>CCC(/C=C/C(C)C1CCC2C3CC=C4CC(O)CCC4(C)C3CCC12C)C(C)C</smiles><smiles>COc1cc2c(c(OC)c1OC)-c1ccc(OC)c(=O)cc1[C@@H](NC(C)=O)CC2</smiles>

Figure 1 Structures of compounds 1 to 10 . These compounds were obtained from B. davidii and identified by spectroscopic and physicochemical analysis.

(C-9), 148.4 (C-4'), $146.9\left(\mathrm{C}-5^{\prime}\right), 131.7\left(\mathrm{C}-1^{\prime}\right), 118.2\left(\mathrm{C}-2^{\prime}\right)$, $114.6\left(\mathrm{C}-6^{\prime}\right), 112.4\left(\mathrm{C}-3^{\prime}\right), 102.3(\mathrm{C}-10), 96.3(\mathrm{C}-6)$, 95.5 (C-8), 78.8 (C-2), $56.2\left({\left.\mathrm{C}-7^{\prime}\right),}^{\prime} 42.6\right.$ (C-3).

Compound 7 (acacetin-7-O- $\alpha$-L-rhamnopyranosyl(16)- $\beta$-D-glucopyranoside [28]), 14 yellow powder; m.p. 266-268 ${ }^{\circ} \mathrm{C}$; molecular formula: $\mathrm{C}_{28} \mathrm{H}_{32} \mathrm{O}_{14}$; ESI-MS: $m / z$ $593[\mathrm{M}+\mathrm{H}]^{+}, 615[\mathrm{M}+\mathrm{Na}]^{+}, 631[\mathrm{M}+\mathrm{K}]^{+} ; 1 \mathrm{H} \mathrm{NMR}$ (DMSO-d6, $500 \mathrm{MHz})$ 8: $12.9\left({ }^{1} \mathrm{H}, \mathrm{s}, 16 \mathrm{OH}-5\right), 8.05$ $\left(2 \mathrm{H}, \mathrm{dd}, J=8.8 \mathrm{~Hz}, \mathrm{H}-3^{\prime}, 5^{\prime}\right), 7.15(2 \mathrm{H}, \mathrm{dd}, J=8.8 \mathrm{~Hz}$, $\left.\mathrm{H}-2^{\prime}, 6^{\prime}\right), 6.93(1 \mathrm{H}, \mathrm{S}, \mathrm{H}-3), 6.79(1 \mathrm{H}, \mathrm{d}, J=2.0 \mathrm{~Hz}, \mathrm{H}-$ 8), $6.45(1 \mathrm{H}, \mathrm{d}, J=2.0 \mathrm{~Hz}, \mathrm{H}-6), 5.07(1 \mathrm{H}, \mathrm{d}, J=7.2 \mathrm{~Hz}$, $\left.18 \mathrm{H}-1^{\prime \prime}\right), 4.55(1 \mathrm{H}, \mathrm{d}, J=1.6 \mathrm{~Hz}, \mathrm{H}-1) ;{ }^{13} \mathrm{C} \mathrm{NMR}$ (DMSO-d $\left.{ }_{6}, 125 \mathrm{MHz}\right)$ 8: 182.6 (C-4), 19164.5 (C-2), 163.5 (C-7), 162.9 (C-5), 161.7 (C-4'), 157.1 (C-9), 129.0
(C-2'), $128.520\left(\mathrm{C}-6^{\prime}\right), 123.2\left(\mathrm{C}-1^{\prime}\right), 115.3\left(\mathrm{C}-3^{\prime}\right), 115.3$ (C-5'), 105.9 (C-10), 104.4 (C-3), 101.0 (C-1"'), 21100.4 (C-1"), 100.2 (C-6), 95.3 (C-8), $76.8\left(\mathrm{C}-3^{\prime \prime}\right), 75.7$ (C-5"), $73.6\left(\mathrm{C}-2^{\prime \prime}\right), 72.622$ (C-4"'), 71.3 (C-3'"'), 70.9 (C-2'"'), 68.4 (C-5"'), $67.7\left(\mathrm{C}-4^{\prime \prime}\right), 66.1\left(\mathrm{C}-6^{\prime \prime}\right), 55.6$ (OMe), 117.8 $\left(\mathrm{C}-6^{\prime \prime \prime}\right)$.

Compound 8 (stigmasterol [20]), white powder; m.p. 166- $168^{\circ} \mathrm{C}$; molecular formula: $\mathrm{C}_{29} \mathrm{H}_{48} \mathrm{O}$; ESI-MS: $\mathrm{m} / \mathrm{z}$ $413[\mathrm{M}+\mathrm{H}]^{+}$; ${ }^{1} \mathrm{H}$ NMR $\left(\mathrm{CDCl}_{3}, 500 \mathrm{MHz}\right) \delta: 5.34\left({ }^{1} \mathrm{H}\right.$, br, s, $4 \mathrm{H}-6), 5.14(1 \mathrm{H}, \mathrm{dd}, J=15.2 \mathrm{~Hz}, 8.8 \mathrm{~Hz}, \mathrm{H}-22)$, $5.08(1 \mathrm{H}, \mathrm{dd}, J=15.2 \mathrm{~Hz}, 8.8 \mathrm{~Hz}, \mathrm{H}-23), 3.49-3.53(1 \mathrm{H}$, $\mathrm{m}, \mathrm{H}-3), \quad 0.7-2.7 \quad(43 \mathrm{H}, \mathrm{m}) ;{ }^{13} \mathrm{C}$ NMR $\left(\mathrm{CDCl}_{3}\right.$, $125 \mathrm{MHz})$ 8: 140.8 (C-5), 138.4 (C-22), 129.3 (C-23), 121.8 (C-6), 71.9 (C-3), 56.9 (C-14), 56.0 (C-17), 51.3 (C- 
24), 50.2 (C-9), 42.4 (C-4), 42.3 (C-13), 40.6 (C-20), 39.8 (C-12), 37.3 (C-1), 37.3 (C-10), 32.7 (C-7), 31.9 (C-8), 31.7 (C-25), 31.7 (C-2), 29.0 (C-16), 25.5 (C-28), 24.5 (C15), 21.3 (C-11), 21.3 (C-21), 21.3 (C-26), 19.5 (C-19), 19.1 (C-27), 12.4 (C-29), 12.1 (C-8).

Compound 9 (ferulic acid [29]), yellow crystal; m.p. 172-174 ${ }^{\circ} \mathrm{C}$; molecular formula: $\mathrm{C}_{10} \mathrm{H}_{10} \mathrm{O}_{4}$; ESI-MS: $\mathrm{m} / z$ $195[\mathrm{M}+\mathrm{H}]^{+}, 217[\mathrm{M}+\mathrm{Na}]^{+} ;{ }^{1} \mathrm{H}$ NMR (DMSO-d6, $500 \mathrm{MHz}) \delta$ : 3.89 (3 H, s, OCH3), 6.33 (1 H, d, $J=16 \mathrm{~Hz}, \mathrm{H}-8), 6.99(1 \mathrm{H}, \mathrm{d}, J=8.4 \mathrm{~Hz}, \mathrm{H}-5), 7.11(1 \mathrm{H}$, $14 \mathrm{dd}, J=8.4 \mathrm{~Hz}, \mathrm{H}-6), 7.18$ (1 H, d, H-2), 7.56 (1 H, d, $J=16 \mathrm{~Hz}, \mathrm{H}-7) ;{ }^{13} \mathrm{C}$ NMR 15 (DMSO-d, $\left.125 \mathrm{MHz}\right) \delta$ : 168.5 (C-1), 149.6 (C-3'), 148.4 (C-4/), 145.1 (C-3), 126.3 $\left(\mathrm{C}-1^{\prime}\right), 123.4\left(\mathrm{C}-6^{\prime}\right), 116.1\left(\mathrm{C}-5^{\prime}\right), 116.0(\mathrm{C}-2), 111.6(\mathrm{C}-$ $\left.2^{\prime}\right), 56.2\left(-\mathrm{OCH}_{3}\right)$.

Compound 10 (colchicine [30]), yellow powder; m.p. 148-150 ${ }^{\circ}$; molecular formula: $\mathrm{C}_{22} \mathrm{H}_{25} \mathrm{NO}_{6}$; ESI-MS: $m$ / $z 400[\mathrm{M}+\mathrm{H}]^{+}, 422[\mathrm{M}+\mathrm{Na}]^{+}, 438[\mathrm{M}+\mathrm{K}] ;{ }^{1} \mathrm{H}$ NMR (CDCl3, $500 \mathrm{MHz})$ 8: $7.63(1 \mathrm{H}, \mathrm{s}, \mathrm{H}-8), 7.35$ (1 H, d, $J=10.9 \mathrm{~Hz}, \mathrm{H}-12), 6.89$ (1 H, d,J=10.9 Hz, H-11), 6.55 (1 H, s, H-4), 4.65 (1 H, dt, H-7), 4.12 (3 H, s, OCH310), $3.94\left(3 \mathrm{H}, \mathrm{s}, \mathrm{OCH}_{3}-2\right), 3.91\left(3 \mathrm{H}, \mathrm{s}, \mathrm{OCH}_{3}-3\right), 3.66$ $\left(3 \mathrm{H}, \mathrm{s}, \mathrm{OCH}_{3}-1\right), 2.38-2.01(1 \mathrm{H}, \mathrm{m}, \mathrm{H}-6) ;{ }^{13} \mathrm{C} \mathrm{NMR}$ $\left(\mathrm{CDCl}_{3}, 125 \mathrm{MHz}\right)$ 8: 179.6 (C-9), 170.2 (C-13), 164.1 (C-10), 153.6 (C-3), 152.6 (C-7a), 151.3 (C-1), 141.7 (C2), 137.0 (C-12a), 135.7 (C-12), 134.4 (C-4a), 130.5 (C8), 125.7 (C-12b), 113.0 (C-11), 107.4 (C-4), 61.7 $\left(\mathrm{OCH}_{3}-1\right), \quad 61.5\left(\mathrm{OCH}_{3}-2\right), \quad 56.5 \quad\left(\mathrm{OCH}_{3}-10\right), \quad 56.2$ $\left(\mathrm{OCH}_{3}-3\right), 52.8$ (C-7), 36.5 (C-6), 29.9 (C-5), 22.9 (C-14).

\section{Anticancer activity}

The potential effects of the extracts from $B$. davidii on the viability of Mgc-803 and Bcap-37 cells were investigated using MTT assay at 5 and $20 \mu \mathrm{M}$, with adriamycin [31] used as the positive control [32,33]. MTT assay is a common method of measuring cell proliferation. The results summarized in Tables 1 and 2 show that luteolin and colchicine possess potent activities against Mgc-803 cells. The activities of luteolin and colchicine at $72 \mathrm{~h}$ after treatment were $13.2 \% \pm 4.2 \%$ and $26.2 \% \pm 9.8 \%$ against Mgc- 803 cells, respectively. And inhibition rates were $50.7 \% \pm 7.4 \%$ and $42.3 \% \pm 9.6 \%$ at $20 \mu \mathrm{M}$, respectively. These results indicated that colchicine showed more potent activity against Mgc- 803 cells than that of luteolin at $5 \mu \mathrm{M}$, but the reverse was true when the concentration was $20 \mu \mathrm{M}$. In addition, the results showed that the inhibitory ratios of luteolin against Mgc-803 cells significantly changed compared with colchicine as the concentration increased. Moreover, the synergistic effect of luteolin and colchicine on the cancer cells were also investigated. Unfortunately, the anticancer activity was not obviously found by combination of luteolin and colchicine. For instance, when the concentration was $5 \mu \mathrm{m}$, the anticancer activity against Mgc-803 cells were
$(27.9 \pm 8.9) \%$ at $72 \mathrm{~h}$ after treatment, whereas the concentration was $20 \mu \mathrm{m}$, the inhibitory ratios at $72 \mathrm{~h}$ after treatment were $(51.3 \pm 2.4) \%$ against Mgc- 803 cells.

Further experiments also found that proliferation of Mgc-803 cells was significantly 4 inhibited by luteolin and colchicine, as shown in Figures 2 and 3. With hydroxycamptothecine (HCPT) and etoposide (VP-16) as positive controls, the $\mathrm{IC}_{50}$ values of luteolin and colchicine on Mgc-803 cells were $19.87 \pm 1.0$ and 18.79 $\pm 1.6 \mu \mathrm{M}$, respectively, and $\mathrm{IC}_{50}$ values of luteolin and colchicine on Bcap-37 cells were $41.78 \pm 2.2$ and 76.01 $\pm 0.6 \mu \mathrm{M}$, respectively. The results also showed that luteolin and colchicine had more potent activities against Mgc-803 cells. Besides, the inhibitory effect on Bcap-37 cells of luteolin was stronger than that of colchicine.

Apoptosis is a physiological pattern of cell death characterized by morphological features and extensive DNA fragmentation, the frequency and time of appearance of which depend on the cell line and the apoptosisinducing signal. It has been well studied that luteolin is capable of inducing cell cycle arrest or apoptosis in various human cancer cells [34-40], such as HT-29 human colon cancer [34], hepatoma cells $[35,36]$, human myeloid leukaemia cells [37], human lung squamous carcinoma $\mathrm{CH} 27$ cell [38], and so on. Moreover, Colchicine can induce cytoskeletal collapse and apoptosis in N-18 neuroblastoma [41] and showed Anti-Mitotic Activity [42]. In order to preliminarily determine the action of luteolin and colchicine, changes in the morphological character of Mgc-803 cells were investigated using acridine orange (AO)/ethidium bromide (EB) staining, Hoechst 33258 staining, and TUNEL (terminal deoxynucleotidyl transferase biotin-dUTP nick end labeling) staining under fluorescence microscopy to determine 3 whether the growth inhibitory activities of luteolin and colchicine were related to the 4 induction of apoptosis.

Since AO is a crucial dye and can stain nuclear DNA across an unbroken cell membrane, whereas EB can only stain cells that had lost an intact cell membrane [43]. Thus, the following phenomena were observed after $\mathrm{AO} /$ EB staining: (1) viable cells have been uniformly stained green; (2) early apoptotic cells have been stained green 9 yellow or displayed green yellow fragments; (3) late apoptotic cells have been stained orange or displayed orange fragments; and (4) necrotic cells have been stained orange to red fluorescing nuclei with no indication of chromatin fragmentation. As shown in Figure 4, all the morphological changes were observed after Mgc-803 cells were treated with luteolin and colchicine for 24, 36, and $48 \mathrm{~h}$. Green live Mgc-803 cells with a normal morphology were seen in the negative control group (Figure 4A). In contrast, early apoptotic cells with yellow green dots and late apoptotic cells with orange dots in Mgc-803 cell nuclei could be seen in the positive control group (Figure 4B and 
Table 1 Growth inhibitory effects of various constituents of B. davidii on different cells at $5 \mu \mathrm{M}$

\begin{tabular}{lcc}
\hline Compound $(\mathbf{5} \boldsymbol{\mu M})$ & \multicolumn{2}{c}{ Growth inhibition (\%) } \\
\cline { 2 - 3 } & $\mathbf{M g c}-\mathbf{8 0 3}$ & $\mathbf{B c a p}-\mathbf{3 7}$ \\
\hline luteolin & $13.2 \pm 4.2$ & $9.6 \pm 6.8$ \\
naringenin & $2.3 \pm 2.9$ & $5.3 \pm 5.4$ \\
puerarin & $0.4 \pm 5.4$ & $5.3 \pm 7.6$ \\
rutin & $8.3 \pm 7.1$ & $0.4 \pm 3.7$ \\
quercetin & $29.2 \pm 4.1^{*}$ & $12.1 \pm 8.2$ \\
hesperetin & $0.0 \pm 2.4$ & $7.9 \pm 6.4$ \\
acacetin-7-O-a-L- rhamnopyranosy & $0.5 \pm 4.3$ & $0.9 \pm 5.2$ \\
(1-6)- $\beta$-D-glucopyranoside & & \\
stigmasterol & $0.8 \pm 3.1$ & $1.3 \pm 7.4$ \\
ferulic acid & $0.9 \pm 6.0$ & $8.2 \pm 5.8$ \\
colchicine & $26.2 \pm 9.8^{*}$ & $19.4 \pm 5.3^{*}$ \\
Adriamycin & $62.5 \pm 4.6^{* *}$ & $47.3 \pm 5.5^{* *}$ \\
\hline *P<0.05 and **P<0.01 versus control. & &
\end{tabular}

C). At the same time, bright green early apoptotic cells with nuclear margination and chromatin coagulation were seen in the experimental group (Figure 4D, G, J, K, M, and $19 \mathrm{~N}$ ), as were orange late apoptotic cells with apoptotic bodies and chromatin fragmentation (Figure 4E, F, H, I, L, and $\mathrm{O}$ ). The results suggested that both of colchicine and luteolin were able to induce apoptosis in Bcap-37 cells. Moreover, it can be seen that colchicine showed more apoptotic activity against Mgc-803 cells than that of luteolin.

Membrane-permeable Hoechst 33258 (a blue fluorescent dye with low cytotoxicity) staining was also performed to investigate the apoptosis-inducing activities of colchicine and luteolin in Mgc-803 cells. Live cells with homogeneous light blue nuclei could be observed under fluorescence microscopy after staining with Hoechst 33258 , and the apoptotic cells displayed bright blue due to karyopyknosis and chromatin condensation after treating with Hoechst 33258, and the nuclei of dead cells could not be stained [43]. As shown in Figure 5, all the mentioned changes could be observed. Compared with the negative control (Figure 5A), a proportion of cells with smaller nuclei and condensed staining appeared in the positive control group (Figure 5B and C). Some Mgc-803 cells nuclei underwent pyknosis after treatment with colchicine for 24 and $36 \mathrm{~h}$, as shown in Figure 5D-I, as did some Mgc-803 cell nuclei after being treated with luteolin for 24 and $36 \mathrm{~h}$, as shown in Figure 5J-O. These results confirmed that colchicine and luteolin could induce apoptosis in Mgc-803 cells and that colchicine had more potent activity against $\mathrm{Mgc}-803$ cells than luteolin.

TUNEL staining was further carried out to confirm the cell apoptosis-inducing activities of colchicine and luteolin. TUNEL staining is a common method for
Table 2 Growth inhibitory effects of various constituents of $B$. davidii on different cells at $20 \mu \mathrm{M}$

\begin{tabular}{lcc}
\hline Compound $(\mathbf{2 0} \boldsymbol{\mu M})$ & \multicolumn{2}{c}{ Growth inhibition (\%) } \\
\cline { 2 - 3 } & Mgc-803 & Bcap-37 \\
\hline Luteolin & $50.7 \pm 7.4^{* *}$ & $28.8 \pm 3.0^{*}$ \\
Naringenin & $4.9 \pm 3.0$ & $12.0 \pm 3.2$ \\
Puerarin & $3.5 \pm 7.0$ & $11.1 \pm 5.3$ \\
Rutin & $21.0 \pm 10.3^{*}$ & $7.3 \pm 4.9$ \\
Quercetin & $31.2 \pm 6.2^{*}$ & $16.1 \pm 6.8$ \\
Hesperetin & $2.9 \pm 4.8$ & $10.6 \pm 3.1$ \\
acacetin-7-O- $a-L-r h a m n o p y r-a n o s y$ & $4.2 \pm 4.6$ & $10.0 \pm 4.0$ \\
(1-6)- $\beta$-D-glucopyranoside & & \\
stigmasterol & $4.7 \pm 5.1$ & $2.6 \pm 8.7$ \\
ferulic acid & $3.9 \pm 5.2$ & $30.2 \pm 5.8^{*}$ \\
colchicine & $42.3 \pm 9.6^{* *}$ & $26.5 \pm 6.2^{*}$ \\
Adriamycin & $92.8 \pm 1.0^{* *}$ & $89.9 \pm 1.3^{* *}$ \\
\hline${ }^{*} P<05$ and ${ }^{* *} P<001$ versus control & &
\end{tabular}

detecting DNA fragmentation that results from apoptotic signaling cascades [44]. Apoptotic cells thus showing a brown color [43]. The experimental results are demonstrated in Figure 6.

From the figure, it could be found that most nuclei in the treatment groups with VP-16 (Figure 6B), HCPT (Figure 6C), colchicine (Figure 6D), and luteolin (Figure 6E) were stained as a discernible brown compared with the control (Figure 6A).

Moreover, the apoptosis ratios induced by colchicine and luteolin caused apoptosis in the Mgc-803 cells were analyzed by flow cytometry with Annexin V/propidium iodide (PI) double staining after treating with colchicine and luteolin for 12, 24, and $36 \mathrm{~h}$. Exposure of the membrane phospholipid phosphatidylserine to the external cellular environment is one of the earliest markers of apoptotic cell death. Annexin V is a calcium-dependent phospholipid-binding protein with high affinity for phosphatidylserine expressed on the cell surface used to differentiate intact cells (Q3; Annexin $\left.\mathrm{V}^{-} / \mathrm{PI}^{-}\right)$. PI does not penetrate whole cells with intact membranes and was used to differentiate between necrotic cells (Q1; Annexin $\left.\mathrm{V}^{-} / \mathrm{PI}^{+}\right)$, late apoptotic cells $\left(\mathrm{Q} 2\right.$; Annexin $\left.\mathrm{V}^{+} / \mathrm{PI}^{+}\right)$, and early apoptotic cells $\left(\mathrm{Q} 4\right.$; Annexin $\left.\mathrm{V}^{+} / \mathrm{PI}^{-}\right)$. The results are shown in Figure 7.

As indicated in Figure 7, the percentages of Q4 (Annexin $\mathrm{V}+/ \mathrm{PI}^{-}$) and $\mathrm{Q} 2$ (Annexin $\mathrm{V}^{+} / \mathrm{PI}^{+}$) were approximately $0.6 \%$ and $4.6 \%$ at $5 \mu \mathrm{M}, 3.1 \%$ and $11.7 \%$ at $10 \mu \mathrm{M}$, and $15.0 \%$ and $44.4 \%$ at $20 \mu \mathrm{M}$, respectively after $12 \mathrm{~h}$ treating with luteolin. While the percentages that were treated for $24 \mathrm{~h}$ were approximately $3.5 \%$ and $12.7 \%$ at $5 \mu \mathrm{M}, 2.2 \%$ and $12.7 \%$ at $10 \mu \mathrm{M}$, and $3.3 \%$ and $45.1 \%$ at $20 \mu \mathrm{M}$ for Q4 and Q2 cells, respectively. In addition, the corresponding values of treating for $36 \mathrm{~h}$ 


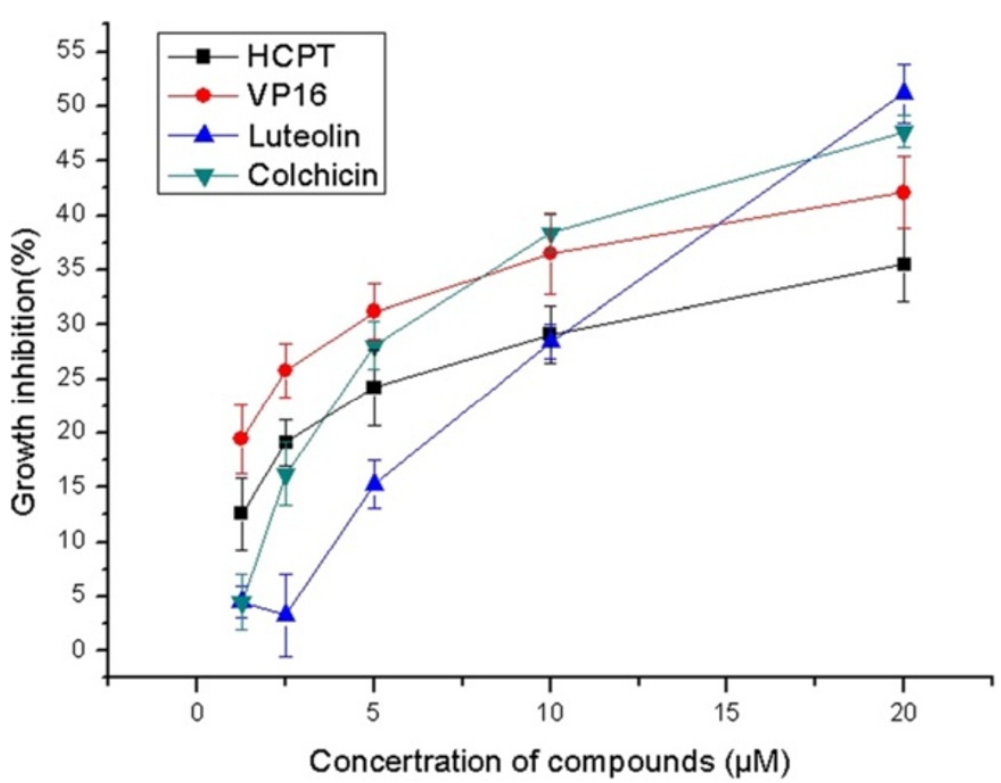

Figure 2 Effects of compounds on proliferation of Mgc-803 cells. After Mgc-803 cells were treated with HCPT, VP-16, luteolin, and colchicine for $72 \mathrm{~h}$ in varying concentrations (1.25 to $20 \mu \mathrm{M}$ ), their growth inhibition was detected using MTT assay. Data are presented as mean $\pm S D, n=3$.

were approximately $2.4 \%$ and $20.8 \%$ at $5 \mu \mathrm{M}, 1.3 \%$ and $11.3 \%$ at $10 \mu \mathrm{M}$, and $15.4 \%$ and $43.7 \%$ at $20 \mu \mathrm{M}$, respectively. When the experiments were treated with colchicine, the percentages (after treating $12 \mathrm{~h}$ ) of Q4 and Q2 cells were approximately $4.4 \%$ and $6.9 \%$ at $5 \mu \mathrm{M}, 7.0 \%$ and $12.9 \%$ at $10 \mu \mathrm{M}$, and $3.9 \%$ and $15.7 \%$ at $20 \mu \mathrm{M}$, respectively. When the time was extended to $24 \mathrm{~h}$, the corresponding percentages were approximately $2.8 \%$ and $12.8 \%$ at $5 \mu \mathrm{M}, 7.7 \%$ and $13.0 \%$ at $10 \mu \mathrm{M}$, and $3.5 \%$ and $19.6 \%$ at $20 \mu \mathrm{M}$, respectively. Moreover, the corresponding percentages (after treating for $36 \mathrm{~h}$ ) were approximately $2.0 \%$ and $14.9 \%$ at $5 \mu \mathrm{M}, 5.9 \%$ and $19.7 \%$ at $10 \mu \mathrm{M}$, and $7.7 \%$ and $35.2 \%$ at $20 \mu \mathrm{M}$, respectively. These results showed that luteolin and colchicine may

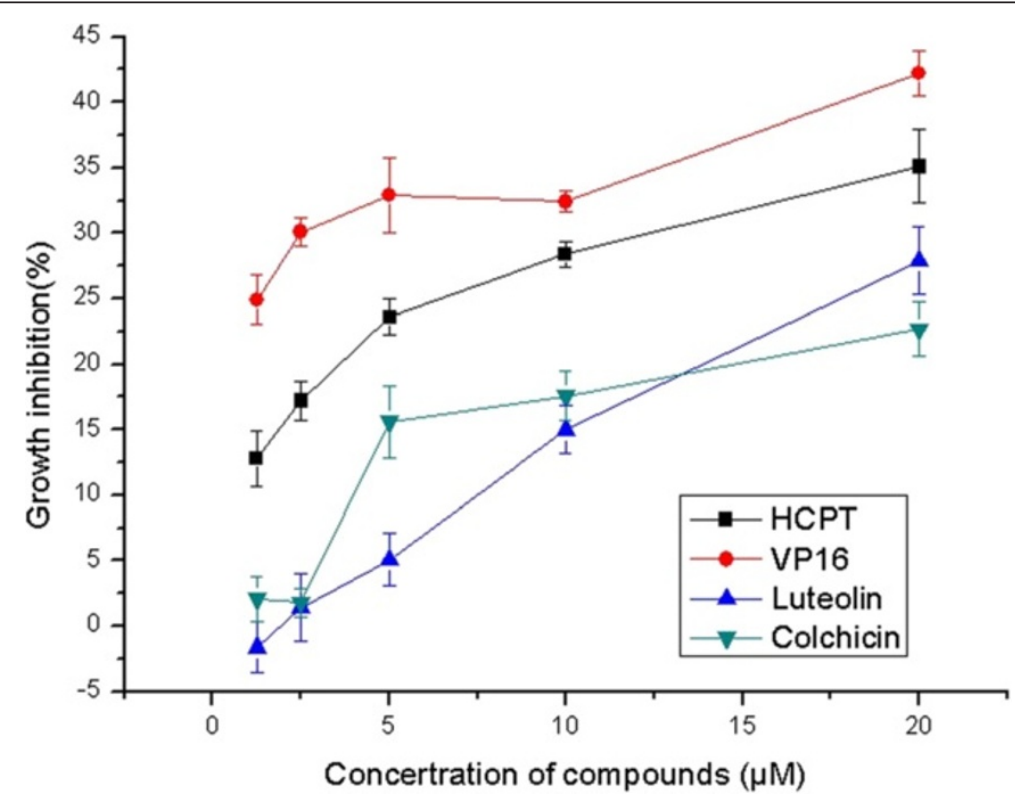

Figure 3 Effects of compounds on proliferation of Bcap-37 cells. After Bcap-37 cells were treated with HCPT, VP-16, luteolin, and colchicine for $72 \mathrm{~h}$ in varying concentrations (1.25 to $20 \mu \mathrm{M}$ ), their growth inhibition was detected using MTT assay. Data are presented as mean \pm SD, $n=3$. 


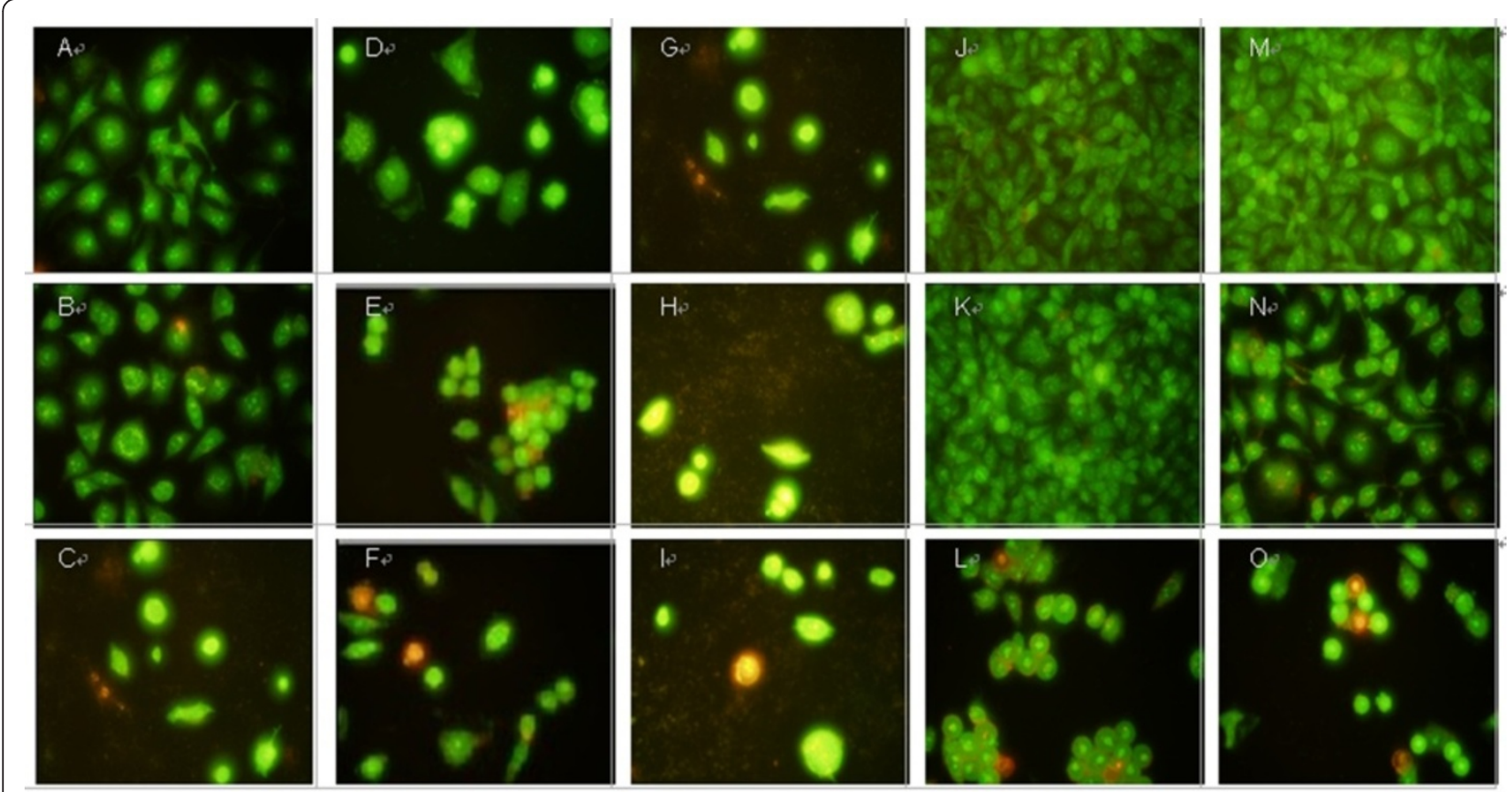

Figure 4 Morphological changes in the nuclei during luteolin- and colchicine-induced apoptosis in Mgc-803 cells detected by AO/EB staining. After treatment with colchicine and luteolin at 5, 10, and $20 \mu \mathrm{M}, \mathrm{Mgc}-803$ cells were stained with AO/EB (100 $\mu \mathrm{g} / \mu \mathrm{M})$ and observed under fluorescence microscopy. A: Negative control (without treatment). B, C: Positive control; treatment with VP-16 and HCPT (20 $\mu \mathrm{M})$ for $24 \mathrm{~h}$, respectively. D-F: Treatment with colchicine (5, 10, and $11 \mu \mathrm{M}$, respectively) for $24 \mathrm{~h}$. G-I: Treatment with colchicine $(5,10$, and $\mu \mathrm{M}, 12$ respectively) for $36 \mathrm{~h}$. J-L: Treatment with luteolin $(5,10$, and $20 \mu \mathrm{M}$, respectively) for $24 \mathrm{~h}$. M-O: Treatment with luteolin $(5,10$, and $20 \mu \mathrm{M}$, respectively) for $48 \mathrm{~h}$.
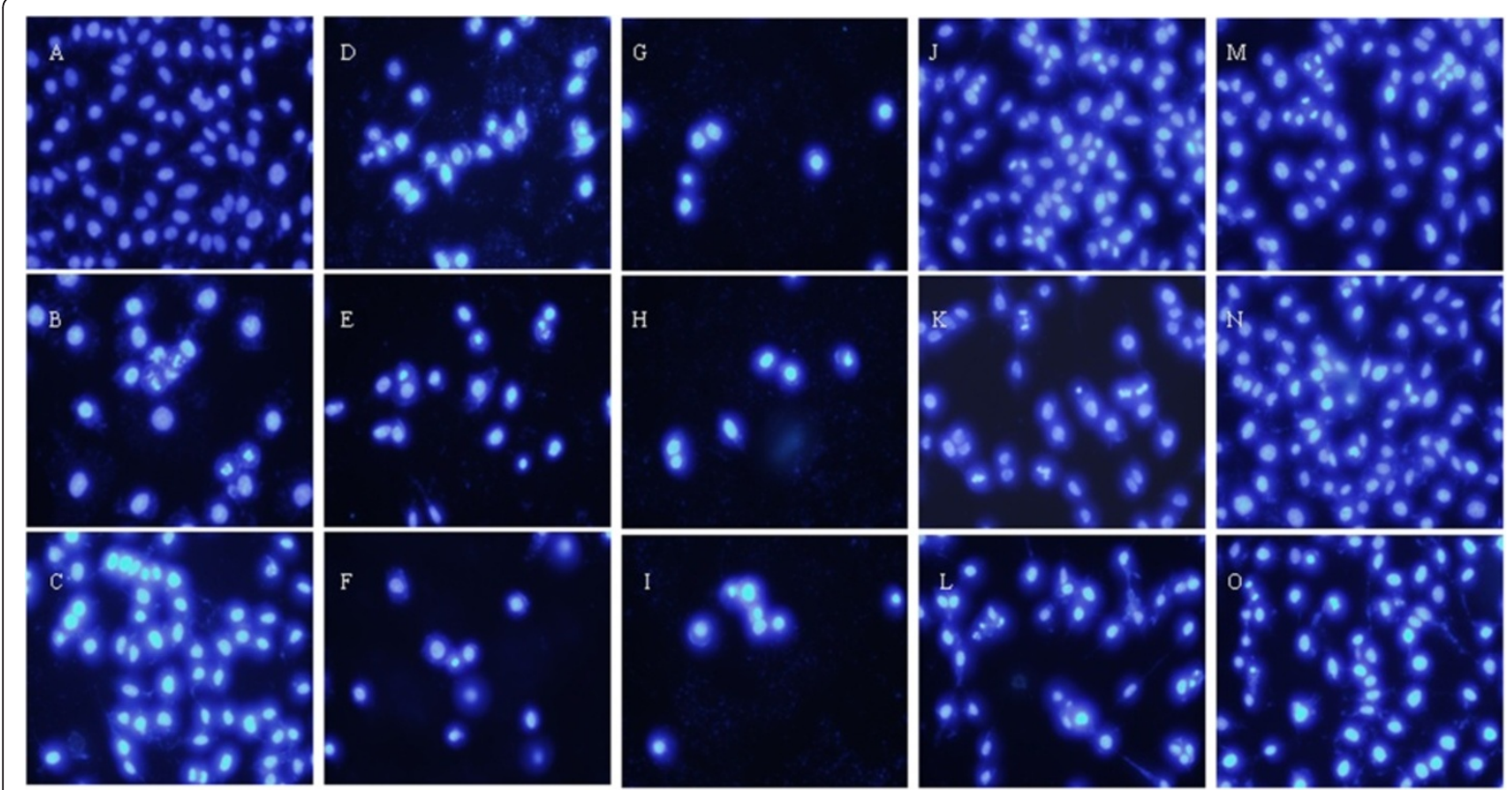

Figure $\mathbf{5}$ Morphological changes in the nuclei during luteolin- and colchicine-induced apoptosis in Mgc-803 cells detected by Hoechst 33258 staining. After treatment with colchicine and luteolin at 5, 10, and $20 \mu \mathrm{M}, \mathrm{Mgc}-803$ cells were stained with Hoechst 33258 and observed under fluorescence microscopy. A: Negative control (without treatment). B, C: Positive control; treatment with VP-16 and HCPT (20 $\mu \mathrm{M})$ for $48 \mathrm{~h}$. D-F: Treatment with colchicine (5, 10, and $20 \mu \mathrm{M}$, respectively) for $24 \mathrm{~h}$. G-I: Treatment with colchicine (5, 10, and $20 \mu \mathrm{M}$, respectively) for $36 \mathrm{~h}$. J-L: Treatment with luteolin (5, 10, and $20 \mu \mathrm{M}$, respectively) for $24 \mathrm{~h} . \mathbf{M - O}$ : Treatment with luteolin (5, 10, and $20 \mu \mathrm{M}$, respectively) for $48 \mathrm{~h}$. 

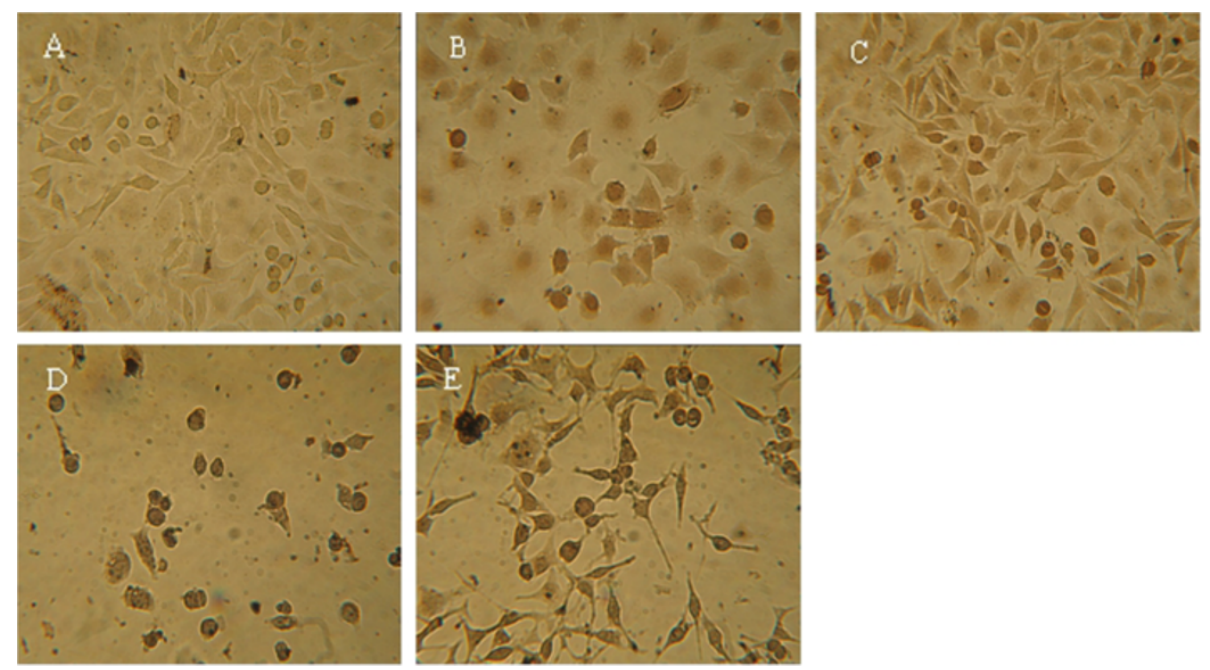

Figure 6 Morphological changes during luteolin and colchicine-induced apoptosis in Mgc- 803 cells detected by TUNEL staining. After treatment with colchicine and luteolin at $20 \mu \mathrm{M}$, Mgc-803 cells were stained with TUNEL and observed under light microscopy. A: Negative control (without treatment). B, C: Positive control; treatment with VP-16 and HCPT (20 $\mu \mathrm{M})$ for $24 \mathrm{~h}$. D: Treatment with colchicine $(20 \mu \mathrm{M})$ for $24 \mathrm{~h}$. E: Treatment with luteolin $(20 \mu \mathrm{M})$ for $24 \mathrm{~h}$.

exert their anticancer activities in Mgc-803 cells by interference of cell proliferation via apoptosis in a doseand time-dependent manner.

In summary, the inhibitory effects observed in response to colchicine and luteolin were associated with the induction of apoptotic cell death.

\section{Conclusions}

B. davidii, a class of Chinese traditional medicine, which showed variety of biologically activity and is widely distributed in southwestern of China. Studies on the chemical constituents of $B$. davidii and their biological activities have focused on the rational development and utilization of this plant.

In the current study, 10 compounds were extracted and identified from $B$. davidii grown in Guizhou, and their cell growth inhibitory effects on Mgc-803 and Bcap-37 cells were evaluated by MTT assay. Among these ten compounds, colchicine $\mathbf{1 0}$ was extracted from $B$. davidii firstly. Both of colchicines and luteolin showed potent anticancer activities on Bcap-37 and BGC-823 cells in a dose-dependent manner. And the IC50 values of luteolin and colchicine on Mgc-803 cells were 19.87 \pm 1.0 and $18.79 \pm 1.6 \mu \mathrm{M}$, respectively, The IC50 values of luteolin and colchicine on Bcap-37 cells were 41.78 \pm 2.2 and $76.01 \pm 0.6 \mu \mathrm{M}$, respectively. This is the first study to have extracted colchicine from $B$. davidii. Moreover, the apoptotic activities induced by colchicine and luteolin in Mgc-803 cells were investigated through AO/EB staining, Hoechst 33258 staining, TUNEL assay, and flow cytometry analysis. The results demonstrated that both compounds are promising adjuvant therapies for treating human carcinoma cells. Further studies are needed to clarify the action mechanism of $B$. davidii on the inhibition of human malignant tumor cell proliferation.

\section{Methods \\ Plant materials}

Fresh $B$. davidii samples were collected from Bijie, Guizhou, in 2008. The plant was identified by Professor Deqing Long (Guiyang Medical University). A voucher specimen was deposited in the Botany and Pharmacognosy Department, School of Pharmacy, Guiyang Medical University.

\section{Extraction and isolation}

Dried B. davidii $(20 \mathrm{~kg}$ ) samples were powdered and extracted with ethanol at room temperature four times for 7 days each. After filtration, the extract was evaporated under reduced pressure for ethanol removal to obtain a water suspension that was sequentially extracted at room temperature with petroleum ether $(5000 \mathrm{~mL})$, ethyl acetate $(5000 \mathrm{~mL}), n$-butanol $(5000 \mathrm{~mL})$, and water $(5000 \mathrm{~mL})$.

The $n$-butanol extract of $B$. davidii (195 g) was chromatographed on a Si gel column (1800 g, 200-300 mesh) eluted with ethyl acetate/methanol mixtures. The fractions eluted with a 10:1 ethyl acetate/methanol ratio yielded $10.2 \mathrm{~g}$ of extract $\mathrm{A}$, whereas those eluted with a 5:1 ethyl acetate/methanol ratio afforded $15.4 \mathrm{~g}$ of extract B. Extract A was subjected to passage over a Si gel column $(250 \mathrm{~mL})$ and eluted with trichloromethane, 


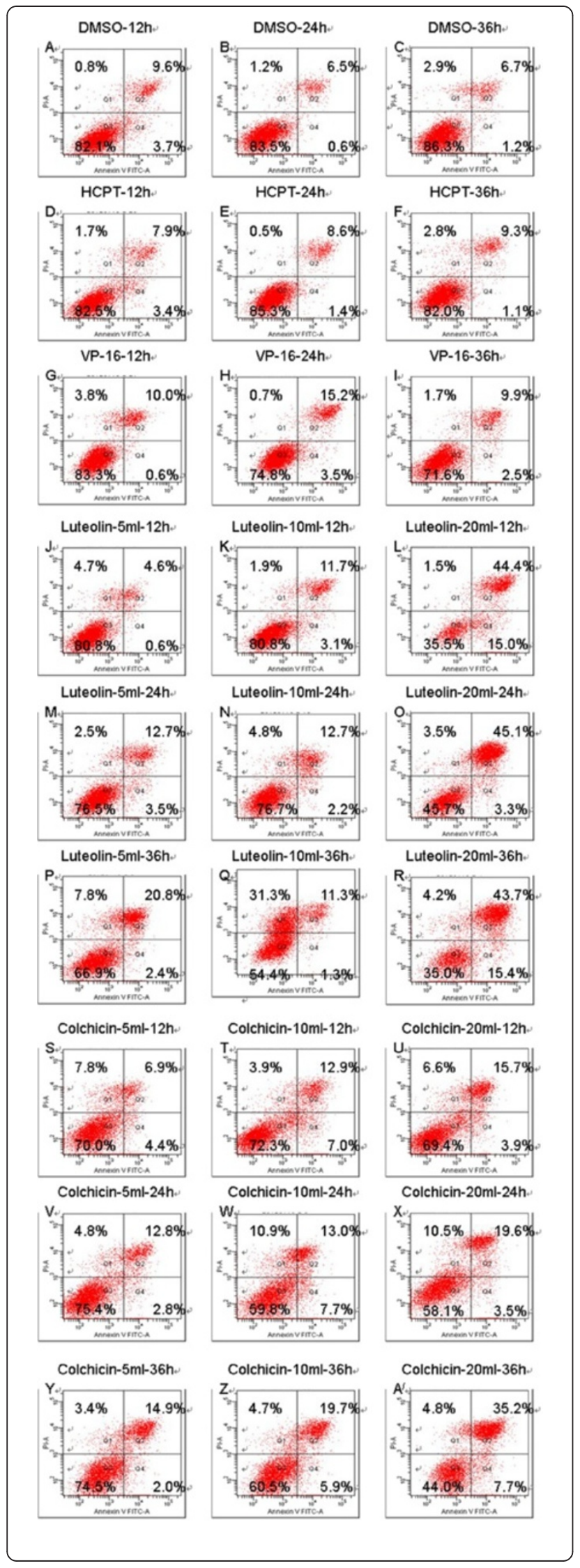

Figure 7 Flow cytometry analysis for apoptosis-inducing activities of colchicine and luteolin in Mgc-803 cells. The appearance of apoptosis cells was detected by flow cytometry using Annexin V/PI staining. A-C: Negative control. D-I: Positive control; treatment with HCPT and VP-16 (20 $\mu \mathrm{M})$ for 12, 24, and 36 h. J-R: Treatment with luteolin $(5,10$, and $20 \mu \mathrm{M})$ for 12, 24, and 36 h. S-A: Treatment with colchicine $(5,10$, and $20 \mu \mathrm{M})$ for 12,24 , and $36 \mathrm{~h}$.

trichloromethane/methanol, and methanol. It was fractionated into three parts (A1-A3): The A1 fraction was purified on Merck Silica gel 60RP-18 (30\%,40\%, and 50\% methanol) to obtain compound $\mathbf{1 0}(18 \mathrm{mg})$ and compound $8(60 \mathrm{mg})$. The A2 fraction was purified on a Sephadex LH-20 column (methanol/water) and then a Si gel column (trichloromethane/methanol, 90:7) to obtain compound $9(43 \mathrm{mg})$. The A3 fraction was purified on Si gel column (trichloromethane/methanol, 70:3) to obtain compound 2 (30 mg).

Extract B was fractionated into four parts (B1-B4) over a Si gel column $(350 \mathrm{~mL})$ eluting with trichloromethane/ methanol (30:1): The B1 fraction was purified on Merck Silica gel 60RP-18 (30\%, 40\%, 50\%, and 100\% methanol) to obtain compound 6 (25 17 mg) and compound 5 (63 mg). The B2 fraction was purified on Merck Silica gel 18 60RP18 (40\%, 50\%, and $100 \%$ methanol) to obtain compound 3 (31 $\mathrm{mg}$ ) and compound 1 (24 mg). The B3 fraction was purified on a Si gel column (trichloromethane/methanol, 10:7) to obtain compound 7 (160 mg). The B4 fraction was purified on a Sephadex LH-20 column (methanol) to obtain compound 4 (42 mg).

\section{Cell lines and culture}

The human gastric cancer cell line Mgc-803, human breast cancer cell line Bcap-37 were grown in RPMI (Roswell Park Memorial Institute) 1640 and supplemented with 10\% fetal bovine serum at $37^{\circ} \mathrm{C}$ in a humidified atmosphere with $5 \%$ $\mathrm{CO}_{2}$; All cell lines were purchased from Institute of Biochemistry and Cell Biology, Shanghai Institute for Biological Sciences, Chinese Academy of Sciences.

\section{Anticancer activity assays MTT assay}

The activities of the compounds in Mgc-803, Bcap-37 were evaluated in vitro using MTT assay. All cell lines (2000 cells/well) were incubated for $24 \mathrm{~h}$ at $37^{\circ} \mathrm{C}$ in an atmosphere of $5 \% \mathrm{CO}_{2}$ before the compounds were added. After treatment with various concentrations of each extract, the cells were incubated for an additional $72 \mathrm{~h}$ at $37^{\circ} \mathrm{C}$ in $5 \% \mathrm{CO} 2$. Subsequently, the medium was removed and the cells in each well were incubated with $100 \mu \mathrm{L}$ of MTT solution $(0.5 \mathrm{mg} / \mathrm{mL})$ for $4 \mathrm{~h}$ at $37^{\circ} \mathrm{C}$. Finally, the mixture was supplemented with sodium dodecyl sulfate and the cells were incubated for $12 \mathrm{~h}$ at $37^{\circ} \mathrm{C}$. 
All experiments were performed in triplicate. The inhibition rate was calculated as follows:

$$
\begin{aligned}
\text { Growth inhibitionrate }(\%)= & \left(\frac{A_{\text {control }}-A_{\text {drug }}}{A_{\text {control }}}\right) \\
& \times 100
\end{aligned}
$$

\section{AO/EB double staining}

Apoptotic morphology was investigated by double staining with $\mathrm{AO}$ and $\mathrm{EB}$ as described by Baskic et al. [45]. In the experiment, Mgc-803 cells were seeded in six-well plates at $5 \times 104$ cells per well in $0.8 \mathrm{~mL}$ of RPMI 1640 medium supplemented with $10 \%$ fetal bovine serum and cultured for $24 \mathrm{~h}$, followed by removal of the culture medium, replacement with fresh medium plus $10 \%$ fetal bovine serum, and supplementation with puerarin and colchicine. After the treatment period, the cover slips with monolayer cells were inverted on a glass slide with $20 \mu \mathrm{L}$ of $\mathrm{AO} / \mathrm{EB}$ stain $(100 \mu \mathrm{g} / \mathrm{mL})$. Fluorescence was read on an IX71SIF-3 fluorescence microscope (OLYMPUS Co., Japan).

\section{Hoechst 33258 staining}

Mgc-803 cells grown on sterile cover slips in six-well tissue culture plates were treated with puerarin and colchicine for a certain range of time. The culture medium containing compounds was removed, and the cells were fixed with $4 \%$ paraformaldehyde for $10 \mathrm{~min}$. After washing twice with PBS, the cells were stained with $5 \mu \mathrm{g} / \mathrm{mL}$ of Hoechst 33258 for $5 \mathrm{~min}$. After rewashing twice with PBS, the percentage of apoptotic cells was determined using an IX71SIF-3 fluorescence microscope. As some of the dead cells were rinsed off as the experiment progressed, the apoptotic ratios could have been underestimated in comparison with those from the MTT assay.

\section{TUNEL staining}

TUNEL assay identifies apoptosis by tagging the 3'-OH ends of DNA fragments with fluorescein [41]. In the present study, Mgc-803 cells grown in six-well tissue culture plates were treated with puerarin and colchicine. The cells were subsequently washed once in $1 \mathrm{~mL}$ of PBS and fixed in 4\% paraformaldehyde for $60 \mathrm{~min}$. After another round of washing with PBS, the cells were incubated with Immunol staining wash buffer (Beyotime) on ice for $2 \mathrm{~min}$. Cells were rewashed once with PBS and then incubated in $0.3 \% \mathrm{H}_{2} \mathrm{O}_{2}$ in methanol at room temperature for $20 \mathrm{~min}$ to inactivate the endogenous peroxidases, after which the cells were washed three times with PBS. Thereafter, the cells were incubated with $2 \mu \mathrm{L}$ of terminal deoxynucleotidyl transferase enzyme and $48 \mu \mathrm{L}$ of biotin-dUTP per specimen for $60 \mathrm{~min}$ at $37^{\circ} \mathrm{C}$. After termination for $10 \mathrm{~min}$, the cells were incubated with $50 \mu \mathrm{L}$ of streptavidin-HRP for $30 \mathrm{~min}$ at room temperature after being washed thrice with PBS.

\section{Flow cytometry analysis}

For measuring apoptosis, Mgc-803 cells were seeded in six-well plates at a density of $5 \times 10^{5}$ cells $/ \mathrm{mL}$ for $24 \mathrm{~h}$ and then treated with puerarin and colchicine at 5,10 , and $20 \mu \mathrm{M}$. After 12,24 , or $36 \mathrm{~h}$, the cells were collected, washed twice with PBS, and centrifuged at room temperature. Subsequently, the Mgc-803 cells were gently resuspended in $500 \mu \mathrm{L}$ of binding buffer. Thereafter, the cells were stained in $5 \mu \mathrm{L}$ of Annexin V/FITC and shaken well. Finally, $5 \mu \mathrm{L}$ of PI was added to these cells; the reaction was incubated for $40 \mathrm{~min}$ in the dark and analyzed using FACSCalibur (Becton Dickinson).

\section{Abbreviations}

HCPT: Hydroxycamptothecine; VP-16: Etoposide; MTT: 3-(4, 5-dimethylthiazol2-yl)-2,5diphenyltetrazolium bromide; AO: Acridine orange; EB: Ethidium bromide; TUNEL: Terminal deoxynucleotidyl transferase-UTP nick end labeling assay.

\section{Competing interests}

The authors declare that they have no competing interests related to the work described in this article.

\section{Authors' contributions}

WY, JW performed the experiments, analyzed the data and wrote the paper $\mathrm{L}-\mathrm{HJ}, \mathrm{DH}$ planned and analyzed the data and B-AS, JW planned the experiments, analyzed the data and wrote the paper. All authors contributed to this study, read and approved the final manuscript.

\section{Acknowledgments}

The authors wish to thank the National Key Program for Basic Research (No. 2010CB 2 126105) and the National Natural Science Foundation of China (No. 21132003) for the financial support.

Received: 7 April 2012 Accepted: 16 July 2012

Published: 31 August 2012

\section{References}

1. Mabberley DJ: The plant-book: A portable dictionary of the higher plants. Cambridge: Cambridge University Press; 1987:707.

2. Houghton PJ: Ethnopharmacology of some Buddleja species. J Ethnopharmacol 1984, 11(3):293-308.

3. Avila JG, De Liverant JG, Martinez A, Martinez G, Munoz JL, Arciniegas A, De Vivar AR: Mode of action of Buddleja cordata verbascoside against Staphylococcus aureus. J Ethnopharmacol 1999, 66(1):75-78.

4. Emam AM, Diaz-Lanza AM, Matellano-Fernandez L, Faure R, Moussa AM, Balansard G: Biological activities of buddlejasaponin isolated from Buddleja madagascariensis and Scrophularia scorodonia. Pharmazie 1997, 52(1):76-77.

5. Houghton PJ, Hikino H: Anti-hepatotoxic activity of extracts and constituents of Buddleja species. Planta Med 1989, 55(2):123-126.

6. Houghton PJ, Mensah AY, lessa N, Hong LY: Terpenoids in Buddleja: relevance to chemosystematics, chemical ecology and biological activity. Phytochemistry 2003, 64(2):385-393.

7. Liao YH, Houghton PJ, Hoult JR: Novel and known constituents from Buddleja 1 species and their activity against leukocyte eicosanoid generation. J Nat Prod 1999, 62(9):1241-1245.

8. Matsuda H, Cai H, Kubo M, Tosa H, linuma M: Study on anti-cataract drugs from natural sources. II. Effects of buddlejae flos on in vitro aldose reductase activity. Biol Pharm Bull 1995, 18(3):463-466.

9. Mensah AY, Houghton PJ, Bloomfield S, Vlietinck A, Vanden-Berghe D: Known and novel terpenes from Buddleja globosa displaying selective antifungal activity against dermatophytes. J Nat Prod 2000, 63(9):1210-1213. 
10. Pardo F, Perich F, Villarroel $L$, Torres $R$ : Isolation of verbascoside, an antimicrobial constituent of Buddleja globosa leaves. J Ethnopharmacol 1993, 39(3):221-222

11. Mensah AY, Sampson J, Houghton PJ, Hylands PJ, Westbrook J, Dunn M, Hughes MA, Cherry GW: Effectd of Buddleja globosa leaf and its constituents relevant to wound healing. J Ethnopharmacol 2001 77(2):219-245

12. Houghton PJ, Hylands PJ, Mensah AY, Hensel A, Deters AM: In vitro Tests and Ethnopharmacolohy Investigations: Wound Healing as an Example. J Ethnopharm 2005, 100(1-2):100-107.

13. Lazebnik YA, Kaufmann SH, Desnoyers S: Cleavage of poly (ADP-ribose) polymerase by a proteinase with properties like ICE. Nature 1994, 371(6495):346-347.

14. Alam R, Alba J, Marcela H: The Antispasmodic Activity of Buddleja scordioides and Buddleja perfoliata on Isolated Intestinal Praparations. Biol Pharm Bull 1996, 29(6):1186-1190.

15. Mensah AY, Sampson J, Houghton PJ: Effectd of Buddleja globosa leaf and its constituents relevant to wound healing. J Ethnopharmacol 2001, 77(2):219-245

16. Debenedetti $S$, Muschietti $L$, Baren C: In vitro antiplasmodial activity of extracts of Argentimian plants. J Ethnopharmacol 2002, 106(1):44-50.

17. Duschatzky CB, Possetto ML, Talarico LB: Evaluation of chemical and antiviral properties of essential oils from South American plant. Antivir Chem Chenother 2005, 16(4):247-251.

18. Martinez-Vazquez M, Ramirez-Apan TO, Aguilar H: Analgesic and antipyretic activities of an aqueous extract and of flavone linarin of Buddleja cordata. Planta Med 1996, 62(2):137-140.

19. Martinez-Vazquez M, Ramirez-Apan TO, Aguilar H: A comparative study of the analgesic and anti-inflammatory activities of pectolinarin isolated from Crisium subcoriaceum and linarin isolated from Buddleja cordata. Planta Med 1998, 64(2):134-137

20. Berghofer R, Holzol J: Biflavonoids in Hypericum perforatum, part I: isolation of 3,8-biapigenin. Planta Med 1987, 53(2):216-217.

21. Wagner $\mathrm{H}$, Chari VM, Sonnenbichler J: 13C-NMR Spektern Naturlich Vorkommender Flavonoide. Tetrahedron 1976, 21:1799-1802

22. Hirakura K, Morita M, Nakajima K: Phenolic glucosides from the root of Pueraria lobata. Phytochemistry 1997, 46(5):921

23. Takeya K, Hideji I: Isoflavonoids and the other constituents in callus tissues of Pueraria lobata. Chen Pharm Bull 1982, 30(4):1496.

24. Markhan KR, Ternai B, Stanley R: Carbon-13NMR studies of flavonoids-II naturally occuring flavonoid glycosides and their acylrted derivatives. Tetrahedron 1978, 34:1398.

25. Wang J, Yang H, Lin ZW: Flavonoids from Bidens pilosa var. radiate. Phytochemistry 1997, 46(7):1275-1278.

26. An Q, Yang CJ, Song Y, Yu K, Xiong ZL, Li FM: Studies on the chemical constituents of the Fruit of Acanthopanax sessiliflorus (Rpr. et Maxim) Seem. Nat Prod Res Dev 2008, 20:765-769.

27. Li J, Chen L, Li B, Liu SJ, Dong JX: Study on the chemical consitituents of Galium aparine L. J Int Pharm Res 2010, 37(5):387-390.

28. Quintin H, Lewin G: Semisynthesis of linarin, acacetin, and 6-iodoapigenin derivatives from diosmin. J Nat Prod 2004, 67(9):1624-1627.

29. Pearl IA, Beyer DL: Reactions of vanillin and its derived compounds $X I$ cinnamic acid derived from vanillin and its related compounds. J Org Chem 1951, 16(2):216-221.

30. Meksuriyen D, Lin LJ, Cordell GA, Mukhopadhyay S, Banerjee SK: NMR Studies of Colchicine and its photoisomers, $\beta$ - and $\gamma$-Lumicolchinies. J Nat Prod 1988, 51(1):88-93.

31. Blum RH, Carter SK: Adriamycin, A new anticancer drug with significant clinical activity. Ann Intern Med 1974, 80(2):249-259.

32. Nakaike S, Yamagishi T, Samata K, Nishida K, Inazuki K, Ichihara T, Migita Y, Otomo S, Aihara H, Tsukagoshi S: In vivo activity on murine tumors of a novel antitumor compound, N-beta-dimethylaminoethyl 9-carboxy-5hydroxy-10- methoxybenzo[a]phenazine-6-carboxamide sodium salt (NC-190). Cancer Chemoth Pharm 1989, 23(3):135-139.

33. Xie YM, Deng Y, Dai XY, Liu J, Ouyang L, Wei YQ, Zhao YL: Synthesis and Biological Evaluation of Novel Acenaphthene Derivatives as Pontential Antitumor Agents. Molecules 2011, 16(3):2519-2526.

34. Lim DY, Jeong Y, Tyner A, Park JH: Induction of cell cycle arrest and apoptosis in HT-29 human colon cancer cells by the dietary compound luteolin. Am J Physiol Gastrointest Liver Physiol 2006, 292:66-75.
35. Selvendiran K, Koga H, Ueno T, Yoshida T, Maeyama M, Torimura T, Yano H, Kojiro M, Sata M: Luteolin promotes degradation in signal transducer and activator of transcription 3 in human hepatoma cells: an implication for the antitumor potential of flavonoids. Cancer Res 2006, 66(9):4826-4834.

36. Lee HJ, Wang CJ, Kuo HC, Chou FP, Jean LF, Tseng TH: Luteolin in human hepatoma HepG2 cells involving mitochondria translocation of Bax/Bak and activation of JNK. Toxicol Appl Pharmacol 2005, 203(2):124-131.

37. Ko WG, Kang TH, Lee SJ, Kim YC, Lee BH: Effects of luteolin on the inhibition of proliferation and induction of apoptosis in human myeloid leukaemia cells. Phytother Res 2002, 16(3):295-298.

38. Leung HW, Wu CH, Lin CH, Lee HZ: Luteolin induced DNA damage leading to human lung squamous carcinoma $\mathrm{CH} 27$ cell apoptosis. Eur $J$ Pharmacol 2005, 508(1-3):77-83.

39. Shi RX, Ong CN, Shen HM: Protein kinase $C$ inhibition and $x$-linked inhibitor of apoptosis protein degradation contribute to the sensitization effect of luteolin on tumor necrosis factor-related apoptosisinducing ligandinduced apoptosis in cancer cells. Cancer Res 2005, 65(17):7815-7823.

40. Shi RX, Ong CN, Shen HM: Luteolin sensitizes tumor necrosis factoralphainduced apoptosis in human tumor cells. Oncogene 2004, 23(16):7712-7721.

41. Brewton LS, Haddad L, Azmitia EC: Colchicine-induced cytoskeletal collapse and apoptosis in $\mathrm{N}-18$ neuroblastoma cultures is rapidly reversed by applied S-100beta. Brain Res 2001, 912(1):9-16.

42. Bhattacharyya B, Panda D, Gupta S, Banerjee M: Anti-mitotic activity of colchicine and the structural basis for its interaction with tubulin. Med Res Rev 2008, 28(1):155-183.

43. Xu XQ, Gao XH, Jin LH, Bhadury PS, Yuan K, Hu DY, Song BA, Yang S: Antiproliferation and cell apoptosis inducing bioactivities of constituents from Dysosma versipellis in PC3 and Bcap-37 cell lines. Cell Div 2011, 6(1):14-26

44. Gavrieli Y, Sherman Y, Ben-Sasson SA: Identification of programmed cell death 7 in situ via specific labeling of nuclear DNA fragmentation. J Cell Biol 1992, 119(3):493-501.

45. Baskic D, Popovic S, Ristic P, Arsenijevic NN: Analysis of cycloheximideinduced apoptosis in human leukocytes: fluorescence microscopy using annexin V/propidium iodide versus acridin orange/ethidium bromide. Cell Bio Int 2006, 30(3):924-932.

doi:10.1186/1747-1028-7-20

Cite this article as: Wu et al: Antiproliferative and cell apoptosisinducing activities of compounds from Buddleja davidii in Mgc-803 cells. Cell Division 2012 7:20.

\section{Submit your next manuscript to BioMed Central and take full advantage of:}

- Convenient online submission

- Thorough peer review

- No space constraints or color figure charges

- Immediate publication on acceptance

- Inclusion in PubMed, CAS, Scopus and Google Scholar

- Research which is freely available for redistribution 